\title{
Mantelzorgers in Europa
}

\section{De rol van betaalde arbeid, generositeit van de gezondheidszorg en nationale normen omtrent zorggedrag}

\author{
Ellen Verbakel
}

Dit onderzoek beantwoordt de vraag waarom sommige mensen wel mantelzorger zijn en andere niet en waarom sommige mantelzorgers intensiever zorgen - dat wil zeggen meer uren per week - dan andere. Specifiek wordt onderzocht welke rol betaalde arbeid, generositeit van de gezondheidszorg en een sterke zorgnorm in het land spelen. Resultaten zijn gebaseerd op multiniveau-analyses op de European Quality of Life Survey 2012 (30.999 respondenten, onder wie 4.377 mantelzorgers). Gemiddeld is 14,6\% van de bevolking in de leeftijd van 18 tot 65 jaar in Europese landen mantelzorger en besteden deze mantelzorgers gemiddeld 12,3 uur per week aan hun mantelzorgtaak. In algemene zin hangt betaalde arbeid negatief samen met (intensief) mantelzorgen. Fulltimers zijn minder vaak mantelzorger dan parttimers en huisvrouwen, maar even vaak als gepensioneerden, werklozen en arbeidsongeschikten. Binnen de groep mantelzorgers besteden fulltimers minder tijd aan hun mantelzorgtaak dan parttimers en mantelzorgen huisvrouwen en gepensioneerden het intensiefst. Een genereuze gezondheidszorg en een sterke familienorm in een land dragen niet significant bij aan de kans om mantelzorger te zijn, maar gaan wel samen met respectievelijk minder en meer intensief mantelzorgen.

\section{Inleiding}

Dit onderzoek gaat in op de vraag waarom sommige mensen wel mantelzorger zijn en andere niet en waarom sommige mantelzorgers intensiever zorgen - dat wil zeggen meer uren per week - dan andere. Specifiek wordt onderzocht welke rol betaalde arbeid hierin speelt en wordt gekeken naar de nationale context waarin individuen zich bevinden: in hoeverre gaan een genereuze gezondheidszorg en een sterke norm om hulpbehoevende ouders te helpen samen met meer of minder mantelzorgen? Deze onderwerpen zijn op dit moment erg actueel in de Nederlandse context van een grootschalige hervorming in de gezondheidszorg: de huidige overheid zet in op een inperking van de formele langdurige zorg en tracht tegelijkertijd een normverandering bij burgers teweeg te brengen met het doel dat mensen het normaler gaan vinden dat men voor elkaar zorgt.

Per 1 januari 2015 is in Nederland een omvangrijke stelselwijziging in de gezondheidszorg doorgevoerd. De Algemene Wet Bijzondere Ziektekosten (AWBZ) is afgeschaft. De extramurale zorg is terechtgekomen in de nieuwe Wet langdurige

* Ellen Verbakel is werkzaam bij de sectie sociologie van de Radboud Universiteit. E-mail: e.verbakel@maw.ru.nl. 
zorg (Wlz), zij het met striktere toelatingscriteria en minder financiering. Zorg voor thuiswonende zorgbehoevenden is overgedragen naar de Wet zorgverzekering (Wzv) waar het persoonlijke verzorging en verpleging betreft; en naar de Wet maatschappelijke ondersteuning 2015 (Wmo 2015) waar het alle andere vormen van zorg en ondersteuning betreft. De verantwoordelijkheid voor de uitvoering van de Wmo ligt bij de gemeenten en ook hier is gekort op de financiering. De stelselwijziging dient als antwoord op de toenemende zorgvraag (en de ermee gepaard gaande toenemende kosten) door de langere levensverwachting en de toename in het aantal chronisch zieken (Colombo et al., 2011; Verbeek-Oudijk et al., 2014). Staatssecretaris Van Rijn motiveert de beleidswijzigingen vanuit de veranderende eisen die mensen stellen - tegenwoordig willen mensen zo lang mogelijk thuis in hun eigen omgeving wonen - en vanuit de mogelijkheden die het biedt om de betrokkenheid tussen burgers in de samenleving te vergroten (TK, 2012/13). In de nieuwe opzet van de gezondheidszorg wordt daarom een grotere inzet van mantelzorg verwacht, dat wil zeggen zorg verleend door mensen uit het eigen netwerk. Immers, het zijn bij uitstek de naasten die ervoor kunnen zorgen dat mensen langer thuis kunnen functioneren en mantelzorg geeft uiting aan de gewenste sterkere onderlinge betrokkenheid (TK, 2012/13). Daarnaast kan ook simpelweg gesteld worden dat meer mantelzorg nodig is om de afname in de formele zorg te compenseren, zodat de zorgbehoefte vervuld blijft.

De hogere verwachtingen van mantelzorg botsen met het streven naar een hogere arbeidsmarktparticipatie. Dit beleidsdoel staat eveneens hoog op de politieke agenda. Om de kosten van een vergrijzende bevolking op te vangen, wordt ingezet op langer doorwerken en meer arbeidsparticipatie onder vrouwen. Echter, het zijn juist deze groepen die vaak geconfronteerd worden met mantelzorgtaken (De Boer et al., 2009). Concurrentie om tijd doet vermoeden dat uitbreiding van beide taken - betaalde arbeid en mantelzorg - niet haalbaar lijkt (Arksey \& Glendinning, 2008; Dautzenberg et al., 2000; Josten \& De Boer, 2015). Dit onderzoek bekijkt daarom in hoeverre betaalde arbeid inderdaad samengaat met een lagere kans op mantelzorgen en met minder intensief mantelzorgen. Als uitbreiding op eerdere studies (zie bijvoorbeeld Josten \& De Boer, 2015), worden niet alleen fulltimers, parttimers en niet-werkenden onderscheiden, maar wordt de laatste groep verder uitgesplitst naar huisvrouwen, gepensioneerden, werklozen, arbeidsongeschikten en overige niet-werkenden. Deze aanpak doet recht aan het feit dat de groep niet-werkenden zeer divers is en zorgt daardoor voor een meer accurate vergelijking van werkenden en niet-werkenden.

De landenvergelijkende opzet van deze studie zet Nederland in internationaal perspectief. Bovenal biedt de opzet inzicht in de houdbaarheid van assumpties achter de huidige beleidswijzigingen. In de motivering rondom deze beleidswijzigingen wordt geïmpliceerd dat mantelzorgers taken van een terugtredende overheid zullen overnemen en dat er meer mantelzorg zal zijn als de opvatting breed gedeeld wordt dat zorgen voor naasten de standaard is. Een landenvergelijkende studie is een manier om na te gaan of de gesuggereerde samenhang tussen mantelzorg enerzijds en generositeit van de formele gezondheidszorg en heersende 
normen anderzijds bestaat. Eerdere landenvergelijkende studies bevatten aanwijzingen dat de hoeveelheid mantelzorg varieert tussen landen (Haberkern \& Szydlik, 2010; Lowenstein et al., 2008; Verbeek-Oudijk et al., 2014). Studies naar verklaringen voor deze variatie zijn schaars. Haberkern en Szydlik (2010) laten zien dat mantelzorg minder vaak voorkomt in landen met genereuze formele gezondheidszorg en in landen waarin de overheid (en niet de familie) als belangrijkste verantwoordelijke in het verlenen van zorg wordt gezien. Brandt et al. (2009) toonden dat in landen met een grote sociale sector inderdaad minder zorg wordt verleend door kinderen aan ouders, maar tegelijkertijd meer huishoudelijke en praktische hulp. Mijn onderzoek biedt op twee belangrijke punten verbeteringen ten aanzien van de bestaande landenvergelijkende literatuur naar mantelzorg, die veelal gebaseerd is op SHARE-data. Ten eerste zullen contextuele verklaringen simultaan worden onderzocht. Dit is essentieel omdat beleidskeuzes worden gemaakt tegen een historische en culturele achtergrond; de gezondheidszorg zal daarom gemiddeld minder genereus zijn in landen met sterke familienormen (Dykstra et al., 2013; Reher, 1998). Het niet tegelijkertijd toetsen van beide verklaringen kan leiden tot onterechte conclusies. Het kleine aantal landen in eerdere studies beperkte de gelijktijdige toetsing van contextuele verklaringen (Brandt et al., 2009; Haberkern \& Szydlik, 2010). Ten tweede benader ik de vraag wie er wel of niet (intensief) mantelzorgt vanuit het perspectief van de potentiële mantelzorger, waar in eerder internationaal vergelijkend onderzoek gekeken werd vanuit de zorgvrager (bepaalt de context of een zorgbehoevende kiest voor formele of informele zorg?). Om te begrijpen of mensen te motiveren zijn om (intensief) te mantelzorgen, is het waardevoller om de invloed van de context te bestuderen vanuit hun perspectief.

In deze bijdrage zullen data van het European Quality of Life Survey 2012 gebruikt worden dat informatie bevat uit 33 Europese landen. De onderzoeksvraag luidt: in hoeverre hangen betaalde arbeid, generositeit van de gezondheidszorg en nationale normen omtrent zorggedrag samen met het al dan niet mantelzorger zijn en de intensiteit van mantelzorgen?

\section{Theorie}

Betaalde arbeid als verklaring voor verschillen in mantelzorg

De algemene veronderstelling is dat betaalde arbeid negatief samenhangt met mantelzorg. Een eerste verklaring is simpelweg concurrentie om tijd: iemand die veel tijd besteedt aan betaald werk, heeft minder tijd beschikbaar voor mantelzorg (Van Putten et al., 2010). Een tweede verklaring is rolconflict (Dautzenberg et al., 2000; Greenhaus \& Beutell, 1985; Lee \& Tang, 2013). Het vervullen van een arbeidsrol en een mantelzorgrol leidt tot een tijdsconflict als bepaalde taken die uit deze rollen voortvloeien op een zelfde moment van de dag moeten plaatsvinden; het is immers niet mogelijk op beide plaatsen fysiek aanwezig te zijn. Daarnaast kan er sprake zijn van een spanningsconflict, als zorgen en stress opgebouwd in de ene rol worden meegenomen naar de andere rol waardoor die rol niet 
meer zo goed vervuld kan worden. Beide vormen van conflict bemoeilijken het combineren van betaald werk en mantelzorg en dit kan leiden tot het zich terugtrekken uit een rol of het verminderen van de intensiteit ervan. Uit deze verklaringen blijkt dat de causaliteit van de relatie tussen betaald werk en mantelzorg niet uni-directioneel is. Recent longitudinaal onderzoek van het SCP heeft uitgewezen dat in Nederland mensen met een grote baan minder vaak overgaan tot het verlenen van mantelzorg dan mensen zonder baan of met een kleine baan (Josten \& De Boer, 2015). Onderhavige studie onderzoekt de relatie tussen betaald werk en mantelzorg voor Europa, maar zonder uitspraken te doen over de richting van het verband. De concrete hypothese luidt: De kans om mantelzorger te zijn (1a) en de intensiteit van mantelzorgen (1b) zijn het laagst voor fulltimers, gevolgd door parttimers en het hoogst voor niet-werkenden.

Om de rol van betaalde arbeid goed te kunnen onderzoeken, is het belangrijk rekening te houden met andere verklarende factoren van (intensief) mantelzorgen die mogelijk samenhangen met betaalde arbeid. Hiervoor wordt het 'moetenwillen-kunnen-kader' gebruikt (Broese van Groenou, 2012; Dykstra \& Van Putten, 2010). De assumptie hierachter is dat de keuze of mensen (intensief) mantelzorgen voortkomt uit drie overwegingen: wat is er nodig? wat wil ik? en wat kan ik? (Broese van Groenou, 2012). 'Moeten' verwijst naar de noodzaak van het verlenen van zorg. De aanwezigheid van een zorgbehoevende in de omgeving is een logische voorwaarde en daarmee de belangrijkste factor die bepaalt of iemand mantelzorger wordt (Brandt et al., 2009; De Boer et al., 2009). Daarnaast bepaalt de mate van zorgbehoefte mede hoeveel hulp er geboden moet worden (Yates et al., 1999). 'Willen' refereert naar het geheel aan normen, attitudes, voorkeuren, verwachtingen en motieven omtrent het zorgen voor hulpbehoevende familieleden. Veel genoemd in dit opzicht is de norm dat men voor familie behoort te zorgen (Bengtson \& Roberts, 1991; Rossi \& Rossi, 1990; Silverstein et al., 1995). Andere redenen om te willen zorgen voor hulpbehoevende familieleden zijn de goede band die men met de hulpbehoevende heeft (Bengtson \& Roberts, 1991; De Boer et al. 2009) of de overtuiging dat de hulpbehoevende beter af is met mantelzorg dan met formele zorg (De Boer et al, 2009), bijvoorbeeld omdat men geen hoge pet op heeft van de gezondheidszorg (Andersen \& Newman, 1973). 'Kunnen' verwijst naar mogelijkheden en restricties die mensen ondervinden om te mantelzorgen, los van de vraag of men zou willen mantelzorgen als de situatie daarom vraagt. Betaalde arbeid kan onder deze factor geschaard worden, evenals andere concurrerende taken zoals zorg voor kinderen (Van Putten et al., 2010). Daarnaast stelt de eigen gezondheid grenzen aan het al dan niet kunnen zorgen voor een ander en aan de intensiteit van die zorgverlening (Brandt et al., 2009; Haberkern \& Szyslik, 2010).

\section{Contextuele verklaringen voor verschillen in mantelzorg}

Een eerste verklaring wordt gezocht in landenverschillen in de generositeit van de gezondheidszorg. Er kan verwacht worden dat genereuze formele langdurige zorgvoorzieningen mantelzorg overbodig maken. Formele zorg en informele zorg zijn in deze visie substituten, dit staat in de literatuur bekend als de crowding- 
out-hypothese (Van Oorschot \& Arts, 2005). Deze gedachte is vaak uitgangspunt in beleid (Lowenstein et al., 2008) en dat lijkt ook voor de hervorming van het Nederlandse gezondheidsbeleid het geval te zijn. In lijn met deze gedachte luidt hypothese 4: De kans om mantelzorger te zijn (2a) en de intensiteit van mantelzorgen (2b) zijn lager naarmate de gezondheidszorg genereuzer is. Landenvergelijkend onderzoek van het Sociaal en Cultureel Planbureau (Verbeek-Oudijk et al., 2014) heeft ondersteuning gevonden voor het idee van substitutie: in landen waar de beschikbaarheid van zorg gefinancierd door publieke middelen groter was, was de intensiteit van onbetaalde zorg lager. Brandt en collega's (2009) tonen een genuanceerder beeld. Zij laten zien dat uitgebreide sociale en zorgvoorzieningen in een land enerzijds samengaan met minder zorgverlening van kinderen aan hun ouders (in overeenstemming met de crowding-out-gedachte), maar anderzijds samengaan met meer hulp van kinderen aan ouders bij huishoudelijke en administratieve taken (bewijs voor de tegengestelde crowding-in-gedachte die steun door de staat en de familie als complementair ziet). Een soortgelijke nuance komt naar voren in Verbakels (2014a) studie naar welbevinden van mantelzorgers: in landen met genereuze langdurige zorgvoorzieningen zijn meer mensen actief als mantelzorger (crowding-in), maar verlenen zij relatief weinig uren zorg (crowding-out).

Een tweede relevant kenmerk waarop landen verschillen betreft het normatieve klimaat. In sommige landen heerst een familialistische cultuur waarin veel belang gehecht wordt aan sterke familiebanden en aan de bereidheid om familieleden te steunen (Kalmijn \& Saraceno, 2008; Reher, 1998). In dit onderzoek zal de sterkte van de familienorm in een land specifiek gericht worden op de plicht van kinderen om mantelzorg te verlenen aan hun ouders. Een dergelijke norm beïnvloedt de mantelzorgkeuze van mensen ongeacht hun eigen normen, omdat mensen gevoelig zijn voor de positieve en negatieve reacties van de omgeving op hun gedrag. Mensen conformeren zich graag aan de verwachtingen van hun omgeving om negatieve sancties te minimaliseren en positieve sancties te maximaliseren. Daarnaast zal een sterke familienorm ervoor zorgen dat mantelzorgen als iets heel gewoons beschouwd wordt. De stap om (veel) te mantelzorgen wordt daarmee naar verwachting vaker genomen zonder er bewust voor te kiezen of zich te laten leiden door belemmeringen. De hypothese die hieruit volgt is: De kans om mantelzorger te zijn (3a) en de intensiteit van mantelzorgen (3b) zijn hoger naarmate de norm om te zorgen voor familieleden sterker wordt onderschreven.

\section{Data}

In deze studie worden data van de European Quality of Life Survey (EQLS) 2012 geanalyseerd. Het EQLS wordt iedere vier jaar uitgevoerd door Eurofond en bevat informatie over objectieve en subjectieve leefomstandigheden van Europese burgers en hun evaluatie van deze omstandigheden. Het verzamelt gegevens in alle lidstaten van de Europese Unie plus Kroatië, IJsland, Macedonië, Montenegro, Servië, Turkije en Kosovo. De dataverzameling en vragenlijsten zijn sterk verge- 
lijkbaar tussen landen. In elk land is een aselecte steekproef van de volwassen bevolking getrokken en zijn face-to-face interviews gehouden. Bruto responspercentages variëren van $14 \%$ in Luxemburg tot $78,3 \%$ in Cyprus. In totaal zijn 43.636 respondenten geïnterviewd in 34 landen. Zie voor meer informatie over de dataverzameling de EQLS-website (http://eurofound.europa.eu/surveys/ european-quality-of-life-surveys-eqls/european-quality-of-life-survey-2012). In deze studie wordt Kosovo buiten beschouwing gelaten vanwege afwezigheid van relevante landinformatie $(\mathrm{N}=1.076)$ en wordt een selectie gemaakt van individuen in de leeftijd van 18 tot 65 jaar $(\mathrm{N}=32.217)$.

Voor het beantwoorden van de onderzoeksvragen worden twee steekproeven gebruikt. De eerste zal gebruikt worden voor het toetsen van de hypthesen over de kans om tot de groep mantelzorgers te behoren. Hiervoor is een steekproef samengesteld van alle respondenten die geen missende waarde hebben op de vraag of ze mantelzorgen (2,8\% verwijderd) of op een van de intervalvariabelen (1,0\% verwijderd). Dit resulteert in een steekproef van 30.999 respondenten in 33 landen. De tweede set van analyses toetst hypothesen over de intensiteit van mantelzorgen onder degenen die mantelzorgen. Hiervoor zijn uit bovengenoemde steekproef alleen mantelzorgers geselecteerd (84,4\% verwijderd) en zijn degenen met een missende waarde op het aantal uren dat ze per week aan mantelzorg besteden verwijderd (1,5\%). Dit resulteert in een steekproef van 4.377 respondenten in 33 landen.

\section{Metingen op individueel niveau}

Het onderscheid tussen mantelzorgers en niet-mantelzorgers wordt gemaakt op basis van de vraag hoe vaak mensen (buiten hun werk) zorgen voor oudere of gehandicapte familieleden. Respondenten die hebben aangegeven dit dagelijks, meerdere dagen per week of één à twee keer per week te doen worden gezien als mantelzorgers. Respondenten die hebben aangegeven nooit of minder dan eens per week voor oudere of gehandicapte familieleden te zorgen, worden gerekend tot de groep niet-mantelzorgers. Deze grens is gekozen om marginale mantelzorg buiten de definitie van mantelzorg te houden. Door het ontbreken van een ondergrens kan de groep 'minder dan eens per week' zeer heterogeen zijn qua intensiteit; deze intensiteit is ook niet af te leiden uit het aantal wekelijkse uren mantelzorg, want deze vraag is, in tegenstelling tot de andere groepen, niet aan hen gesteld. In de steekproef is $15,6 \%$ van de respondenten mantelzorger.

De intensiteit van mantelzorgen is gemeten in het aantal uren per week dat aan de mantelzorgtaak wordt besteed. Het aantal uren varieert van 1 tot 168 (waarbij 168 staat voor ' $24 / 7$ ') met een gemiddelde van 12,3 . Omdat de verdeling van deze variabele rechtsscheef is, zal in de analyses een logtransformatie worden toegepast.

Deelname aan betaalde arbeid wordt gemeten in zeven categorieën: mensen met een fulltime baan (35 uur per week of meer, inclusief overwerk), mensen met een parttime baan (1 tot 35 uren per week, inclusief overwerk), huisvrouwen ${ }^{1}$, gepen- 
sioneerden, werklozen, arbeidsongeschikten en overige niet-werkenden (bijvoorbeeld studenten).

Alternatieve verklaringen voor (intensief) mantelzorgen worden gestructureerd aan de hand van het 'moeten-willen-kunnen-kader'. De factor 'moeten' wordt ten eerste gemeten door de zorgbehoefte in het netwerk. Als een respondent aangeeft dat (a) hijzelf of iemand anders in het huishouden en/of (b) iemand die niet in hetzelfde huishouden woont maar wel dichtbij staat, het afgelopen jaar gebruik heeft gemaakt of willen maken van langdurige zorg, wordt het netwerk als zorgbehoevend beschouwd. Helaas is het niet mogelijk de zorgbehoefte van de respondent zelf te scheiden van de zorgbehoefte van diens omgeving. Ten tweede wordt co-residentie met de ouders opgevat als teken dat (schoon)ouders hulpbehoevend zijn. Controle voor leeftijd filtert een andere belangrijke reden voor co-residentie tussen ouders en kinderen (te weten, jongeren hebben de stap naar zelfstandigheid nog niet gemaakt) er veelal uit. De factor 'willen' wordt benaderd door religiositeit, omdat verondersteld wordt dat religies het belang van naastenliefde en zorgen voor anderen expliciet benadrukken. Religiositeit wordt gemeten aan de hand van de frequentie van het bijwonen van religieuze diensten (los van huwelijken, begrafenissen en doopsels) en varieert van (bijna) iedere dag tot nooit op een vijfpuntsschaal. Daarnaast wordt iemands oordeel van de kwaliteit van de langdurige zorg in het land meegenomen op basis van de veronderstelling dat mensen een voorkeur voor mantelzorg ontwikkelen als zij het gevoel hebben dat hun naaste geen goede zorg zal krijgen in het formele zorgsysteem. Respondenten hebben de langdurige formele zorg in hun land beoordeeld met een rapportcijfer. Bijna een derde van de respondenten heeft zich onthouden van een mening; dit is waarschijnlijk een groep die geen ervaring heeft met langdurige zorgfaciliteiten. Om deze groep te behouden is de variabele verder gecategoriseerd: een rapportcijfer van 1 tot en met 5 betekent 'onvoldoende'; een 6 of 7 betekent 'voldoende'; en een 8, 9 of 10 betekent 'goed'. De factor 'kunnen' wordt (naast deelname aan betaalde arbeid) in de eerste plaats gemeten middels de gezondheid van de respondent, afgemeten aan het ondervinden van beperkingen in het dagelijks leven als gevolg van een chronische aandoening. Onder chronische aandoening vallen fysieke of mentale gezondheidsproblemen, ziekten of handicaps die (naar verwachting) langer dan zes maanden duren. Respondenten die geen chronische aandoening rapporteren of aangeven daardoor niet gehinderd te worden in het dagelijks leven worden onderscheiden van respondenten die aangeven enigszins of ernstige beperkingen te ervaren in hun dagelijks leven door hun aandoening. Ten tweede wordt gemeten of de respondent een zorgtaak voor (klein)kinderen heeft. Om het tijdsbestedingsargument te benadrukken is niet gekeken naar de aanwezigheid van (jonge) kinderen in het huishouden, maar is gebruikgemaakt van informatie van de respondent hoe vaak deze zorgt voor zijn of haar kinderen of kleinkinderen. Hierbij is onderscheid gemaakt tussen mensen die (a) nooit, (b) maximaal een paar dagen per week of (c) dagelijks zorgen voor (klein)kinderen.

Controlevariabelen zijn sekse, leeftijd in categorieën (18-24, 25-34, 35-44, 45-54, 55-64), burgerlijke staat (gehuwd, gescheiden, verweduwd en alleenstaand, nooit gehuwd geweest) en opleidingsniveau (in zeven ISCED-niveaus). Missende waar- 
den op categorische variabelen zijn in een aparte categorie opgenomen. ${ }^{2}$ Zoals aangegeven, zijn respondenten met missende waarden op intervalvariabelen (religiositeit en opleidingsniveau) buiten de analyse gelaten. Tabel 1 toont de beschrijvende informatie van alle individuele kenmerken.

Tabel 1 Beschrijvende informatie van individuele gegevens

\begin{tabular}{|c|c|c|c|c|c|c|c|}
\hline & \multirow[b]{2}{*}{ Bereik } & \multicolumn{3}{|c|}{$\begin{array}{l}\text { Mantelzorgen: ja/nee } \\
(\mathrm{N}=30.999)\end{array}$} & \multicolumn{3}{|c|}{$\begin{array}{l}\text { Intensiteit van mantel- } \\
\text { zorgen }(\mathrm{N}=4.377)\end{array}$} \\
\hline & & $\%$ & Gem. & St.dev. & $\%$ & Gem. & St.dev. \\
\hline Mantelzorgen: ja/nee & $0 / 1$ & 15,6 & & & & & \\
\hline $\begin{array}{l}\text { Intensiteit van mantel- } \\
\text { zorgen (uren per week) }\end{array}$ & $1-168$ & & & & & 12,28 & 18,10 \\
\hline $\begin{array}{l}\text { Intensiteit van mantel- } \\
\text { zorgen (uren per week, } \\
\text { logtransformatie) }\end{array}$ & $0-5,12$ & & & & & 1,90 & $\mathrm{I}, 07$ \\
\hline \multicolumn{8}{|l|}{ Betaalde arbeid } \\
\hline Fulltime & $0 / 1$ & 45,9 & & & $4 I, 3$ & & \\
\hline Parttime & $0 / 1$ & 9,2 & & & $\mathrm{II}, 5$ & & \\
\hline Huisvrouw & $0 / 1$ & 9,6 & & & 13,6 & & \\
\hline Gepensioneerd & $0 / 1$ & 10,4 & & & 12,0 & & \\
\hline Werkloos & $0 / 1$ & 10,6 & & & 10,3 & & \\
\hline Arbeidsongeschikt & $0 / 1$ & 2,6 & & & 3,4 & & \\
\hline Overig & $0 / 1$ & 10,8 & & & 7,4 & & \\
\hline Missende waarde & $0 / 1$ & 0,9 & & & 0,6 & & \\
\hline \multicolumn{8}{|l|}{$\begin{array}{l}\text { Zorgbehoefte in het net- } \\
\text { werk }\end{array}$} \\
\hline Nee & $0 / 1$ & 83,6 & & & 70,9 & & \\
\hline Ja & $0 / 1$ & 10,8 & & & 24,4 & & \\
\hline Missende waarde & $0 / 1$ & 5,7 & & & 4,7 & & \\
\hline Co-residentie met ouders & $0 / 1$ & 17,5 & & & 23,3 & & \\
\hline Religiositeit & $0-4$ & & $\mathrm{I}, 0 \mathrm{I}$ & $\mathrm{I}, 07$ & & 1,15 & 1,13 \\
\hline \multicolumn{8}{|l|}{$\begin{array}{l}\text { Oordeel over de kwaliteit } \\
\text { van langdurige zorg in het } \\
\text { land }\end{array}$} \\
\hline Onvoldoende & $0 / 1$ & 30,4 & & & 37,0 & & \\
\hline Voldoende & $0 / 1$ & 22,1 & & & 25,2 & & \\
\hline Goed & $0 / 1$ & 15,6 & & & 16,9 & & \\
\hline Geen oordeel & $0 / 1$ & 31,4 & & & 20,6 & & \\
\hline Missende waarde & $0 / 1$ & 0,5 & & & 0,3 & & \\
\hline \multicolumn{8}{|l|}{$\begin{array}{l}\text { Beperkt in dagelijks leven } \\
\text { door chronische aan- } \\
\text { doening }\end{array}$} \\
\hline $\begin{array}{l}\text { Nee, of geen chronische } \\
\text { aandoening }\end{array}$ & $0 / 1$ & 82,5 & & & 77,8 & & \\
\hline
\end{tabular}




\begin{tabular}{|c|c|c|c|c|c|c|c|}
\hline & \multirow[b]{2}{*}{ Bereik } & \multicolumn{3}{|c|}{$\begin{array}{c}\text { Mantelzorgen: ja/nee } \\
(\mathrm{N}=30.999)\end{array}$} & \multicolumn{3}{|c|}{$\begin{array}{l}\text { Intensiteit van mantel- } \\
\text { zorgen }(\mathrm{N}=4.377)\end{array}$} \\
\hline & & $\%$ & Gem. & St.dev. & $\%$ & Gem. & St.dev. \\
\hline $\mathrm{Ja}$, in enige of sterke mate & $0 / 1$ & 16,8 & & & 21,2 & & \\
\hline Missende waarde & $0 / 1$ & 0,7 & & & 1,0 & & \\
\hline \multicolumn{8}{|c|}{$\begin{array}{l}\text { Zorgtaak voor (klein)kinde- } \\
\text { ren }\end{array}$} \\
\hline Nooit & $0 / 1$ & 39,8 & & & 28,9 & & \\
\hline $\begin{array}{l}\text { Maximaal een paar dagen } \\
\text { per week }\end{array}$ & $0 / 1$ & 20,1 & & & 24,2 & & \\
\hline Dagelijks & $0 / 1$ & 38,7 & & & 45,0 & & \\
\hline Missende waarde & $0 / 1$ & 1,3 & & & 1,8 & & \\
\hline Vrouw & $0 / 1$ & 57,1 & & & 65,6 & & \\
\hline \multicolumn{8}{|l|}{ Leeftijd } \\
\hline $18-24$ & $0 / 1$ & 12,1 & & & 6,8 & & \\
\hline $25-34$ & $0 / 1$ & 19,8 & & & 12,0 & & \\
\hline $34-44$ & $0 / 1$ & 22,5 & & & 21,9 & & \\
\hline $45-54$ & $0 / 1$ & 22,8 & & & 31,6 & & \\
\hline $55-64$ & $0 / 1$ & 22,9 & & & 27,8 & & \\
\hline \multicolumn{8}{|l|}{ Burgerlijke staat } \\
\hline Gehuwd & $0 / 1$ & 62,9 & & & 67,0 & & \\
\hline Gescheiden & $0 / 1$ & 10,6 & & & 12,1 & & \\
\hline Verweduwd & $0 / 1$ & 4,3 & & & 4,4 & & \\
\hline Alleenstaand, nooit gehuwd & $0 / 1$ & 21,6 & & & 16,1 & & \\
\hline Missende waarde & $0 / 1$ & 0,5 & & & 0,4 & & \\
\hline Opleidingsniveau & $0-6$ & & 3,25 & $\mathrm{I}, 27$ & & 3,21 & $\mathrm{I}, 28$ \\
\hline
\end{tabular}

Bron: European Quality of Life Survey, 2012

\section{Metingen op landniveau}

De generositeit van het gezondheidsstelsel wordt gemeten aan de hand van de overheidsuitgaven aan de gezondheidszorg (per hoofd van de bevolking en gecorrigeerd voor koopkrachtpariteit (Purchasing Power Parity) in Amerikaanse dollars). Gegevens zijn afkomstig uit de databank van de United Nations en betreffen het gemiddelde over de jaren 2009-2011. Alternatieve maten die specifieker gericht zijn op langdurige zorg, zoals het aantal bedden in verzorgings- en bejaardentehuizen per 1.000 65-plussers of de proportie 65-plussers die langdurige zorg ontvangt, correleren hoog met de uitgavenmaat (respectievelijk 0,71 en 0,61), maar waren slechts voor een beperkt aantal landen beschikbaar (respectievelijk voor 26 en 17 landen).

De sterkte van de familienorm in een land is afgeleid uit individuele informatie uit de European Values Study (EVS) 2008 en (na weging) geaggregeerd naar landni- 
veau. In de EVS is gevraagd naar opvattingen over de verantwoordelijkheid van volwassen kinderen tegenover hun ouders wanneer hun ouders gedurende lange tijd zorg nodig hebben. Aan respondenten zijn twee stellingen voorgelegd met de vraag welke het beste aansluit bij hun denkbeelden: (a) volwassen kinderen hebben de plicht om langdurige zorg te verlenen aan hun ouders, zelfs als dat ten koste gaat van hun eigen welzijn en (b) volwassen kinderen hebben hun eigen leven en moeten niet gevraagd worden hun eigen welzijn op te offeren in het belang van hun ouders. Voor ieder land is het percentage bepaald dat de eerste stelling onderschrijft. Vergelijkbare informatie is niet beschikbaar in de European Quality of Life Survey; daardoor kan de individuele familienorm niet in de modellen opgenomen worden om compositie-effecten volledig uit te sluiten. Met name individuele religiositeit en het in huis hebben van (schoon)ouders hangen naar verwachting echter positief samen met sterke familienormen en zullen de compositie-effecten deels verdisconteren. Beide contextuele kenmerken zullen in de analyses worden gestandaardiseerd.

\section{Analyseaanpak}

De toetsing van de hypothesen gebeurt aan de hand van multiniveau-analyses waarin respondenten genest zijn in landen. Hypothesen omtrent de kans om mantelzorger (versus niet-mantelzorger) te zijn, zijn getoetst met logistische regressieanalyses, uitgevoerd op de totale set van respondenten $(\mathrm{N}=30.999)$. Hypothesen omtrent de intensiteit van mantelzorgen zijn getoetst met lineaire regressieanalyses op een subset van respondenten, namelijk de mantelzorgers ( $\mathrm{N}=4.377)$. De modellen zijn stapsgewijs opgebouwd. In Model 1 zijn alleen de individuele kenmerken opgenomen (tabel 3). In Model 2 en 3 zijn de twee landkenmerken één voor één toegevoegd aan de individuele kenmerken. Ten slotte is een totaalmodel geschat waarin alle predictoren tegelijkertijd zijn opgenomen. Dit betekent dat de effecten van de landkenmerken voor hun onderlinge samenhang gecontroleerd zijn; dit is belangrijk om overschatting tegen te gaan. Modellen 2, 3 en 4 staan in tabel 4 (de coëfficiënten van de individuele variabelen worden hierin niet weergegeven, omdat ze nauwelijks verschillen met die in Model 1). 


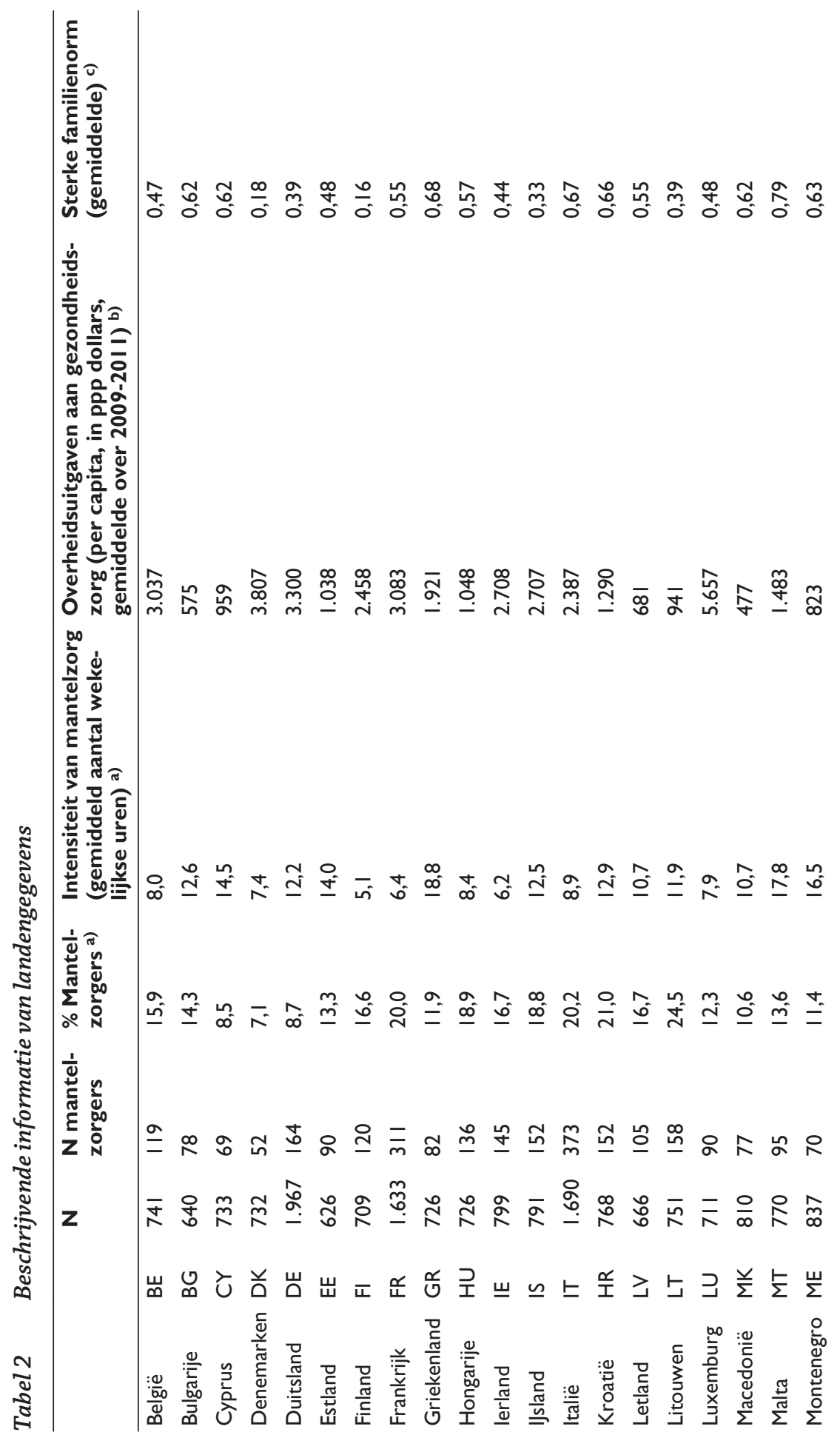




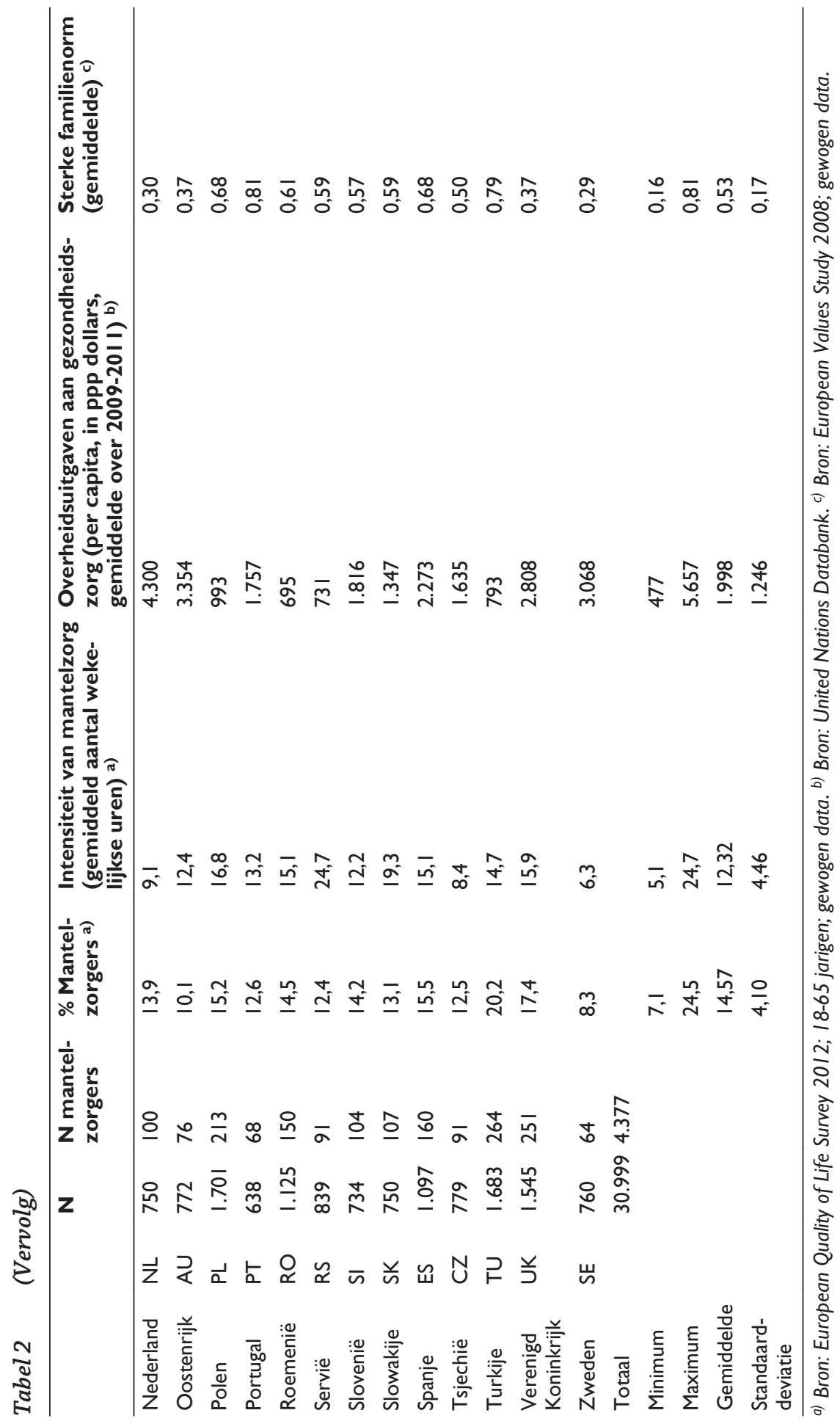




\section{Resultaten}

Beschrijving van landenverschillen in mantelzorg

Gemiddeld wordt in de Europese landen die in deze studie worden onderzocht door $14,6 \%$ van de bevolking mantelzorg verleend. Dit percentage varieert echter van $7,1 \%$ in Denemarken tot $24,5 \%$ in Litouwen (zie figuur 1). Nederland zit ongeveer op het Europees gemiddelde met 13,9\%. Uit het nulmodel van de multiniveau-analyse, dat wil zeggen het model zonder predictoren, is op te maken dat ondanks de hier beschreven verschillen tussen landen - slechts een klein deel van de variantie in de kans om mantelzorger te zijn ligt op het landniveau (3,2\%); de rest van de variantie $(96,8 \%)$ is toe te schrijven aan het individuele niveau. ${ }^{3}$

De intensiteit van mantelzorg varieert eveneens tussen landen. Gemiddeld besteden mantelzorgers in Europa 12,3 uur per week aan mantelzorg, maar in Finland ligt het wekelijks aantal uren gemiddeld op 5,1 tegen 24,7 in Servië (zie figuur 1). Wat intensiteit betreft zit Nederland onder het gemiddelde met 9,1 uur per week. De samenhang tussen de proportie mantelzorgers en de intensiteit van mantelzorg in een land is licht negatief $(r=-0,11)$, maar niet significant. Er is dus geen duidelijke aanwijzing voor het principe dat veel handen (veel mantelzorgers) licht werk (weinig uren) maken of juist voor het idee dat landen gekenmerkt kunnen worden door hetzij een grote hetzij een beperkte mantelzorginzet, zowel in termen van omvang van de mantelzorggroep als de hoeveelheid uren die zij mantelzorgen. Het nulmodel in de multiniveau-analyse wijst uit dat de intraklassecorrelatie 0,26 bedraagt. ${ }^{4}$ Dit geeft aan dat ongeveer een kwart van de variantie in intensiteit van mantelzorgen is toe te schrijven aan het landniveau en ongeveer driekwart aan het individuele niveau.

Figuur 2 laat zien in hoeverre de verschillen tussen landen in de omvang van de mantelzorggroep en de intensiteit van mantelzorg samenhangen met landenverschillen in overheidsuitgaven aan gezondheidszorg en aan de sterkte van de familienorm. De getoonde verbanden zijn bivariaat en niet gecontroleerd voor compositieverschillen tussen landen; zij zijn bedoeld voor een eerste aanwijzing voor de houdbaarheid van de hypothesen. Het percentage mantelzorgers in een land is lager naarmate er meer uitgegeven wordt aan de gezondheidszorg $(r=-0,20)$; ook de intensiteit van mantelzorg is lager naarmate de gezondheidszorguitgaven hoger zijn $(r=-0,50)$. Dit duidt op het substitutiemechanisme: formele zorg maakt mantelzorg minder noodzakelijk. Alleen de samenhang met intensiteit van mantelzorg is statistisch significant. Sterke familienormen gaan samen met een hoger percentage mantelzorgers $(r=0,16)$ en een sterkere intensiteit van mantelzorg $(r=0,56)$; wederom is alleen het verband met intensiteit van mantelzorgen statistisch significant. De richtingen van de bivariate relaties ondersteunen de theoretische verwachtingen. Figuur 2 toont tevens de positie van Nederland in internationaal perspectief. Qua overheidsuitgaven aan gezondheidszorg scoort Nederland erg hoog; na Luxemburg het hoogst van alle onderzochte landen. In Nederland heerst geen sterke familienorm die voorschrijft dat kinderen hun 

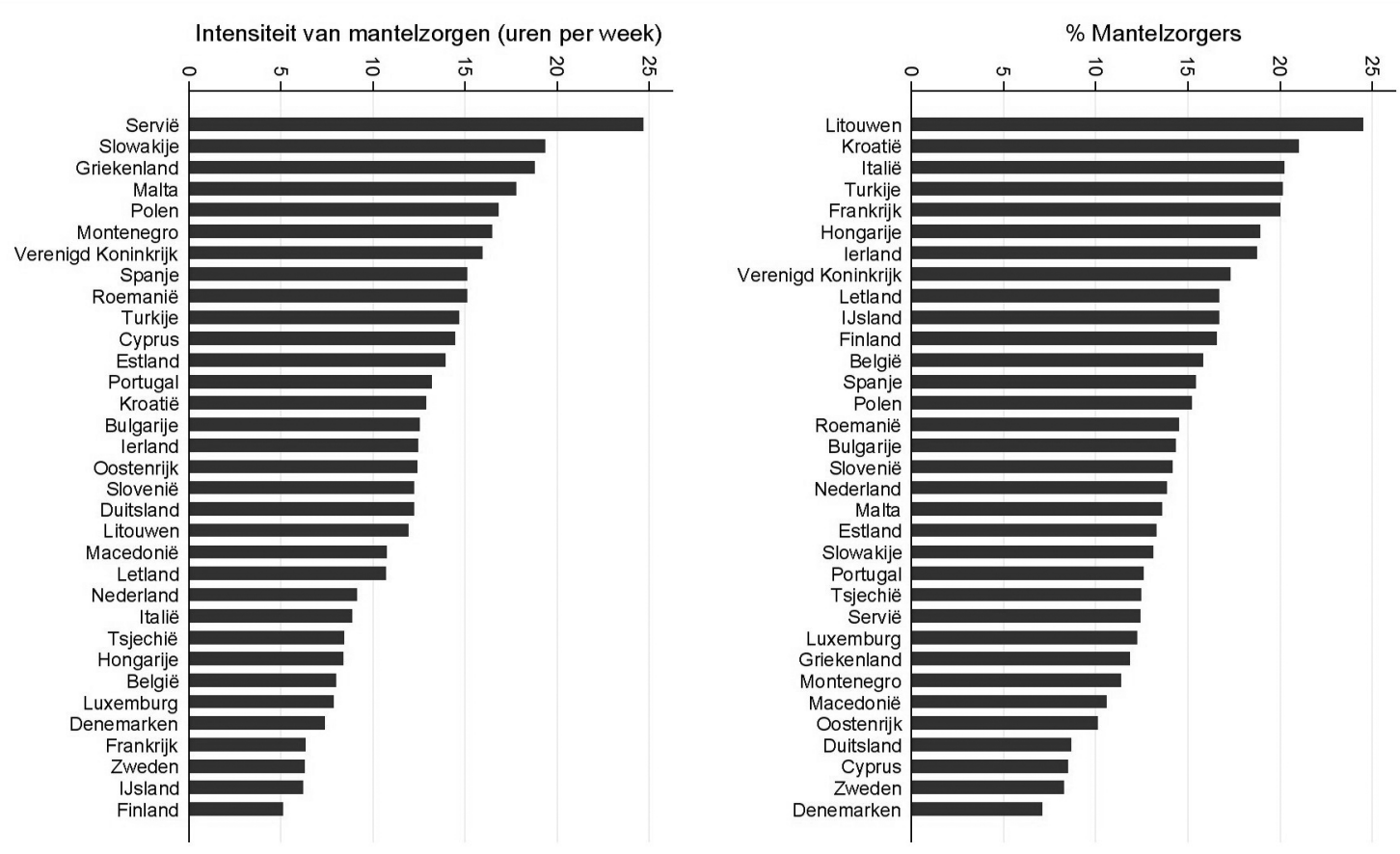

Bron: European Quality of Life Survey 2012; 18-65-jarigen; gewogen data

\section{Figuur 1 Percentage mantelzorgers en intensiteit van mantelzorgen (uren per week) naar land}

ouders moeten helpen. Samen met de Scandinavische landen zit Nederland in het lage spectrum van de schaal.

\section{Verklaringen voor variatie in mantelzorg}

Tabel 3 toont de effecten van individuele factoren op de kans om wel (versus niet) te mantelzorgen (Model 1a) en op de intensiteit van mantelzorgen (Model 1b). De centrale focus ligt op het verband tussen betaalde arbeid en mantelzorg. Parttimers zijn 1,3 keer en huisvrouwen 1,4 keer zo vaak mantelzorger als fulltimers (verschil tussen parttimers en huisvrouwen is niet significant). Alle andere nietwerkzame groepen (gepensioneerden, werklozen, arbeidsongeschikten en overige niet-werkenden) zijn niet significant vaker of minder vaak mantelzorger dan fulltimers. In zekere zin tonen deze resultaten het verwachte verband dat de kans mantelzorger te zijn afneemt met de hoeveelheid tijd die men op de arbeidsmarkt doorbrengt. Echter, enige nuance is op zijn plaats, aangezien van de niet-werkzame groepen alleen huisvrouwen daadwerkelijk vaker mantelzorger zijn dan fulltimers. Deze resultaten tonen aan dat het belangrijk is verschillende groepen van niet-werkenden te onderscheiden, aangezien het mantelzorggedrag van met name huisvrouwen heel anders is dan dat van andere groepen zonder betaald 

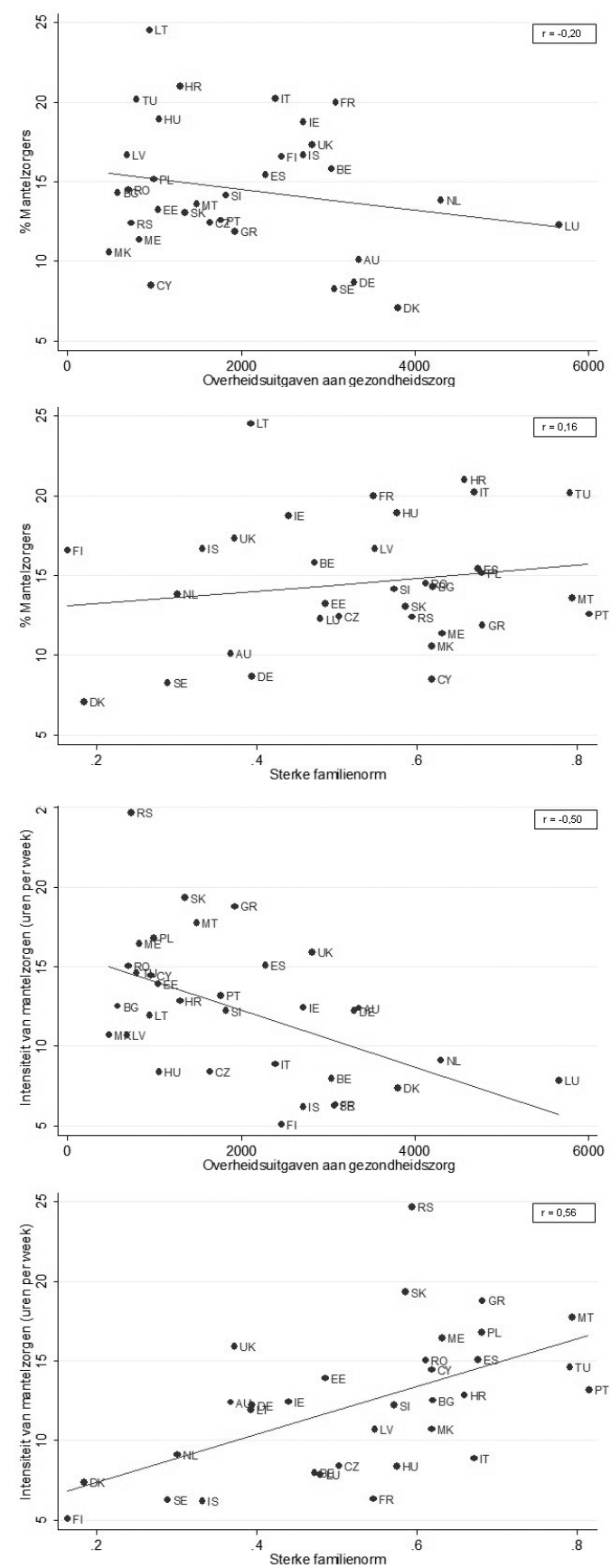

Figuur 2 Samenhang tussen proportie mantelzorgers en intensiteit van mantelzorgen in een land met (a) overheidsuitgaven aan gezondheidszorg en (b) sterke familienorm 
werk. De hier gepresenteerde coëfficiënten zijn gecontroleerd voor de overige verklarende factoren. Indien niet constant gehouden wordt voor verschillen in 'moeten', 'willen', 'kunnen' en achtergrondkenmerken, zijn ook werklozen, gepensioneerden en arbeidsongeschikten significant vaker mantelzorger dan fulltimers (maar minder vaak dan parttimers en huisvrouwen); het verschil tussen parttimers en huisvrouwen wordt eveneens verklaard door deze achterliggende factoren (resultaten van model met alleen betaalde arbeid als verklaring te verkrijgen bij de auteur).

De resultaten in Model $1 \mathrm{~b}$ tonen eveneens een negatieve relatie tussen betaalde arbeid en intensiteit van mantelzorg. Omdat de afhankelijke variabele een logtransformatie is van het aantal uren dat mantelzorgers per week zorg verlenen, kunnen de coëfficiënten (indien vermenigvuldigd met 100) geïnterpreteerd worden als de procentuele verandering in uren mantelzorg als de onafhankelijke variabele met één eenheid toeneemt. Parttime werkende mantelzorgers besteden $11 \%$ meer uren aan mantelzorg dan fulltime werkende mantelzorgers. Niet-werkzame groepen mantelzorgen nog intensiever, met huisvrouwen en gepensioneerden als koplopers (respectievelijk 42 en 41\% meer uren dan fulltimers). Ook hier geldt dat ons inzicht in de relatie tussen betaalde arbeid en mantelzorg vergroot wordt door de groep niet-werkenden verder uit te splitsen. Huisvrouwen en gepensioneerden zijn substantieel en significant intensievere mantelzorgers dan de overige niet-werkenden. Indien geen rekening gehouden zou worden met verschillen tussen respondenten in 'moeten', 'willen', 'kunnen' en achtergrondkenmerken, zouden de gevonden verschillen tussen de categorieën van betaalde arbeid uitgesprokener zijn, maar zijn de patronen nagenoeg gelijk.

De rol van de overige verklaringen kan als volgt worden samengevat. Kenmerken die de noodzaak van mantelzorg aangeven ('moeten') blijken belangrijke voorspellers voor de kans te gaan mantelzorgen en de intensiteit van mantelzorgen. Mensen met een zorgbehoefte in hun directe omgeving die samenwonen met hun (schoon)ouders hebben respectievelijk 3,3 en 4,4 keer zoveel om kans mantelzorger te zijn als mensen die dat niet doen. Daarnaast besteden zij respectievelijk $11 \%$ en $43 \%$ meer tijd aan hun mantelzorgtaak dan mantelzorgers zonder zorgbehoefte in het netwerk of die een zelfstandig huishouden voeren. Factoren die indicatief zijn voor het 'willen' mantelzorgen (religiositeit en een minder positief oordeel over de kwaliteit van langdurige zorg in het land) blijken inderdaad samen te gaan met een hogere kans mantelzorger te zijn, maar zijn slechts ten dele bepalend voor de intensiteit van mantelzorgen. Van indicatoren voor mogelijkheden en restricties van mantelzorg ('kunnen') - anders dan betaalde arbeid blijkt geen belemmerende werking uit te gaan. In tegendeel, mantelzorg komt vaker en intensiever voor onder hen die ook een zorgtaak voor kinderen hebben en die beperkingen ervaren als gevolg van chronische aandoeningen. Ten slotte laten de resultaten zien dat vrouwen vaker (1,4 keer) en meer uren (19\%) mantelzorgen dan mannen; dat (intensief) mantelzorgen toeneemt met de leeftijd; dat verweduwden en nooit-gehuwden minder vaak mantelzorger zijn dan gehuwden en dat gescheiden mensen intensiever mantelzorgen dan gehuwden; dat oplei- 
dingsniveau niet samenhangt met de kans mantelzorger te zijn, maar dat hoogopgeleiden minder intensief mantelzorgen dan laagopgeleiden.

Tabel 3 Invloed van individuele kenmerken op (a) kans op mantelzorgen en (b) intensiteit van mantelzorg

\begin{tabular}{|c|c|c|c|c|}
\hline & \multirow{2}{*}{\multicolumn{2}{|c|}{$\begin{array}{l}\text { Mantelzorgen (ja versus } \\
\text { nee) } \\
\text { Model Ia }{ }^{\text {a) }}\end{array}$}} & \multirow{2}{*}{\multicolumn{2}{|c|}{$\begin{array}{l}\text { Intensiteit van mantel- } \\
\text { zorgen (in uren per } \\
\text { week, logtransformatie) } \\
\text { Model Ib }{ }^{\text {b) }}\end{array}$}} \\
\hline & & & & \\
\hline & or & se & $\mathrm{b}$ & se \\
\hline \multicolumn{5}{|l|}{ Individuele kenmerken } \\
\hline \multicolumn{5}{|l|}{ Betaalde arbeid (ref=fulltime) } \\
\hline Parttime & $\mathrm{I}, 27 * *$ & 0,08 & $0,11 *$ & 0.05 \\
\hline Huisvrouw & $1,37 * *$ & 0,09 & $0,42 * *$ & 0.05 \\
\hline Gepensioneerd & 0,96 & 0,06 & $0,4 I^{* *}$ & 0.06 \\
\hline Werkloos & 1,09 & 0,07 & $0,25 * *$ & 0.05 \\
\hline Arbeidsongeschikt & $\mathrm{I}, 00$ & 0,11 & $0,24 * *$ & 0.09 \\
\hline Overig & 0,93 & 0,07 & $0,19 * *$ & 0.07 \\
\hline $\begin{array}{l}\text { Zorgbehoefte in het netwerk } \\
\text { (ref=nee) }\end{array}$ & $3.27^{* *}$ & 0,15 & $0,11 * *$ & 0,04 \\
\hline Co-residentie met ouders (ref=nee) & $4.4 I^{* *}$ & 0,24 & $0,43 * *$ & 0,04 \\
\hline Religiositeit (0-4) & $1.10 * *$ & 0,02 & 0,01 & 0,01 \\
\hline \multicolumn{5}{|l|}{$\begin{array}{l}\text { Oordeel over de kwaliteit van } \\
\text { langdurige zorg in het land } \\
\text { (ref=onvoldoende) }\end{array}$} \\
\hline Voldoende & 0,94 & 0,04 & $-0,10 * *$ & 0.04 \\
\hline Goed & $0,85 * *$ & 0,04 & $-0,09 *$ & 0.04 \\
\hline Geen oordeel & $0,61 * *$ & 0,03 & $-0,13^{* *}$ & 0.04 \\
\hline $\begin{array}{l}\text { Beperkt in dagelijks leven door } \\
\text { chronische aandoening (ref=nee) }\end{array}$ & $1.10^{*}$ & 0,05 & $0,11 * *$ & 0,04 \\
\hline \multicolumn{5}{|l|}{$\begin{array}{l}\text { Zorgtaak voor (klein)kinderen } \\
\text { (ref=nooit) }\end{array}$} \\
\hline Maximaal een paar dagen per week & $1,45^{* *}$ & 0,07 & $-0,20 * *$ & 0.04 \\
\hline Dagelijks & $1,70 * *$ & 0,08 & $-0,08 \sim$ & 0.04 \\
\hline Vrouw (ref=man) & $1.40 * *$ & 0,05 & $0,19 * *$ & 0,03 \\
\hline \multicolumn{5}{|l|}{ Leeftijd (ref=45-54) } \\
\hline $18-24$ & $0,22 * *$ & 0,02 & $-0,66 * *$ & 0.08 \\
\hline $25-34$ & $0,3 I^{* *}$ & 0,02 & $-0,17 * *$ & 0.05 \\
\hline $35-44$ & $0,59 * *$ & 0,03 & $-0,06$ & 0.04 \\
\hline $55-64$ & 0,93 & 0,05 & $0,15 * *$ & 0.04 \\
\hline \multicolumn{5}{|l|}{ Burgerlijke staat (ref=gehuwd) } \\
\hline Gescheiden & 0,95 & 0,05 & $0,10^{*}$ & 0.05 \\
\hline Verweduwd & $0,74 * *$ & 0,06 & 0,01 & 0.07 \\
\hline
\end{tabular}




\begin{tabular}{|c|c|c|c|c|}
\hline & \multirow{2}{*}{\multicolumn{2}{|c|}{$\begin{array}{l}\text { Mantelzorgen (ja versus } \\
\text { nee) } \\
\text { Model Ia a) }\end{array}$}} & \multirow{2}{*}{\multicolumn{2}{|c|}{$\begin{array}{l}\text { Intensiteit van mantel- } \\
\text { zorgen (in uren per } \\
\text { week, logtransformatie } \\
\text { Model l b b) }\end{array}$}} \\
\hline & & & & \\
\hline Alleenstaand, nooit gehuwd & $0,86^{*}$ & 0,05 & 0,08 & 0.05 \\
\hline Opleidingsniveau (0-6) & 1.01 & 0,01 & $-0,04^{* *}$ & 0,01 \\
\hline Intercept & $0.10 * *$ & 0,01 & $\mathrm{I}, 79 * *$ & 0,09 \\
\hline $\mathrm{N}$ respondenten & 30.999 & & 4.377 & \\
\hline $\mathrm{N}$ landen & 33 & & 33 & \\
\hline Variantie op landniveau & 0,12 & 0,04 & 0,27 & 0,04 \\
\hline Variantie op individueel niveau & & & 0,96 & 0,01 \\
\hline
\end{tabular}

$\sim p<0,10 ; * p<0,05 ; * * p<0,01$

a) logistische multiniveau-analyse; odds ratio's en standaardfouten.

b) multiniveau-analyse; ongestandaardiseerde regressiecoëfficiënten en standaardfouten.

Bron: European Quality of Life Survey 2012

Resultaten omtrent contextuele invloeden worden gepresenteerd in tabel 4. Verwacht werd dat een genereuze gezondheidszorg de behoefte aan veel mantelzorg zou wegnemen met minder mantelzorgers en minder intensieve mantelzorg tot gevolg. Daarnaast werd verwacht dat een sterke familienorm die uitdraagt dat kinderen voor hun ouders behoren te zorgen indien ze dat nodig hebben, de omvang van de mantelzorgersgroep en de intensiteit van mantelzorg positief zou beïnvloeden. Voor beide afhankelijke variabelen worden verbanden in de voorspelde richting gevonden, maar alleen voor wat betreft de intensiteit van mantelzorgen kunnen we spreken van statistisch significante verbanden. De resultaten in de multiniveau-analyse komen daarmee overeen met de eerder besproken bivariate resultaten. Model $2 \mathrm{~b}$ in tabel 4 laat zien dat als er in een land één standaarddeviatie meer overheidsuitgaven aan gezondheidszorg zijn, de intensiteit van mantelzorgen gemiddeld 17,2\% lager is. Eén standaarddeviatie sterkere familienormen gaat gepaard met een 16,9\% hogere intensiteit van mantelzorgen (Model $3 \mathrm{~b})$. Omdat hoge overheidsuitgaven aan gezondheidszorg lager zijn in landen met een sterke familienorm $(r=-0,57)$, is het belangrijk beide landkenmerken tegelijk op te nemen (Model 4b). De sterkte van de effecten reduceert daarmee met respectievelijk 30 en 41\%. Echter, de conclusies blijven ongewijzigd. Beide landkenmerken verklaren afzonderlijk van elkaar waarom er variatie is in de intensiteit van mantelzorgen.

\section{Conclusie}

Deze studie is ingegaan op de vraag waarom sommige mensen wel en andere niet mantelzorger zijn en waarom - onder de mantelzorgers - sommige dat intensiever doen dan andere. Hierbij stonden drie factoren centraal: de rol van betaalde arbeid van het individu, de generositeit van de gezondheidszorg en de contextuele norm om hulpbehoevende ouders te helpen. Resultaten zijn gebaseerd op multi- 


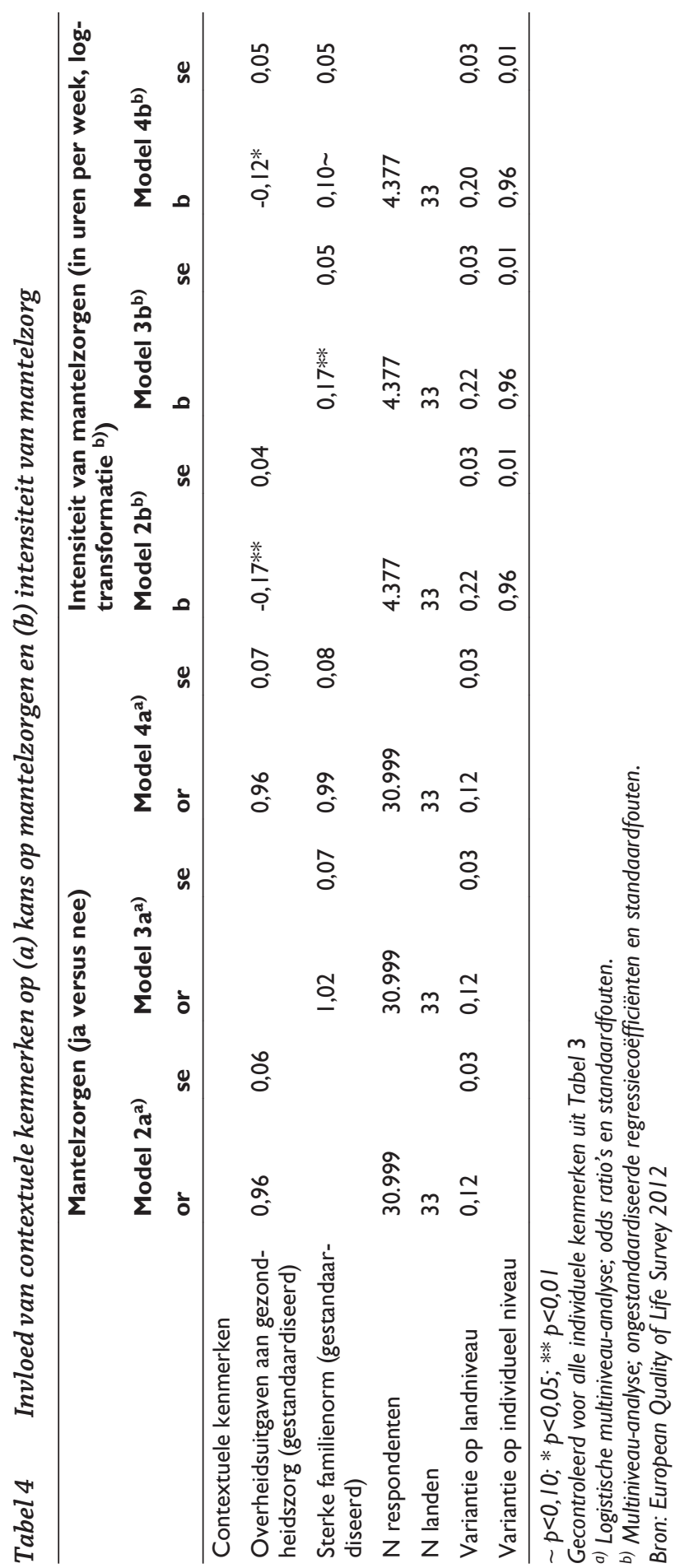


niveau-analyses met 30.999 respondenten uit 33 Europese landen die ondervraagd zijn in het European Quality of Life Survey 2012.

Een eerste conclusie is dat fulltime werk en mantelzorg niet goed verenigbaar lijken. Mensen met een fulltime baan zijn minder vaak mantelzorger dan mensen met een parttime baan en dan huisvrouwen. Binnen de groep mantelzorgers besteden fulltimers minder tijd aan hun mantelzorgtaak dan parttimers en mantelzorgen huisvrouwen en gepensioneerden het intensiefst. Het uitsplitsen van de categorie niet-werkenden blijkt belangrijk om de relatie tussen betaalde arbeid en mantelzorg goed voor ogen te krijgen. De groep zonder betaald werk is erg divers als het om mantelzorg gaat; hen als één groep beschouwen verbloemt belangrijke onderlinge verschillen en maakt de vergelijking met fulltimers en parttimers minder informatief. Huisvrouwen - en als het om intensiteit van mantelzorg gaat ook gepensioneerden - nemen vaker en meer mantelzorg op zich dan werklozen, arbeidsongeschikten en overige niet-werkenden; zelfs als constant gehouden wordt voor veel andere verschillen tussen deze groepen.

Het is belangrijk te benadrukken dat deze studie geen causaliteit kan vaststellen. Mogelijk leidt een (intensieve) mantelzorgtaak tot het terugtrekken uit een fulltime baan of zijn er achterliggende factoren die zowel de kans op mantelzorg als de kans op niet-fulltime werk bepalen. Voor de Nederlandse situatie heeft longitudinaal onderzoek van het SCP (Josten \& De Boer, 2015) echter uitgewezen dat de negatieve relatie tussen betaalde arbeid en mantelzorg vooral voortkomt uit een minder sterke neiging met mantelzorg te beginnen onder fulltimers dan uit een neiging het aantal werkuren te reduceren als men eenmaal een mantelzorgtaak heeft opgepakt. De beperkte mantelzorginzet onder fulltimers, zoals gevonden in dit onderzoek, suggereert dat het beleidsdoel van hogere arbeidsparticipatie mogelijk niet goed samengaat met hogere verwachtingen van mantelzorg. Maar, de resultaten van deze studie suggereren eveneens dat het stimuleren van vrouwen om de arbeidsmarkt te betreden niet noodzakelijkerwijs grote consequenties hoeft te hebben voor het aanbod van mantelzorgers, zo lang het om deeltijdbanen gaat; immers, parttimers zijn even vaak mantelzorger als huisvrouwen. Tegelijkertijd echter zijn huisvrouwen en gepensioneerden (gezien de leeftijdsselectie in deze studie zijn dit vroeggepensioneerden) de meest intensieve mantelzorgers. Dit mantelzorg-potentieel wordt mogelijk aangetast als zij gestimuleerd worden te gaan werken of langer te blijven doorwerken.

Een tweede conclusie is dat dit onderzoek geen bewijs heeft gevonden dat de kans om mantelzorger te zijn hoger is naarmate de gezondheidszorg minder genereus of de familienorm in het land sterker is. Wel blijkt de intensiteit van mantelzorgen negatief samen te hangen met generositeit van de gezondheidszorg en positief samen te hangen met een sterke familienorm, zelfs als de effecten van beide landkenmerken voor elkaar worden gecontroleerd. Theoretisch betekent deze conclusie ondersteuning voor de crowding-out-gedachte. Echter, het feit dat dit alleen gevonden wordt voor de intensiteit van mantelzorgen en niet voor de kans op mantelzorgen past in de lijn van eerdere bevindingen die suggereren dat de crowding-out- en crowding-in-werking van genereuze gezondheidszorg genuanceerd 
ligt. De beleidsimplicatie van deze conclusie is dat de impliciete assumpties achter de huidige hervormingen in de gezondheidszorg ondersteund worden voor zover het om de intensiteit van mantelzorg gaat. Het terugdringen van de overheidsuitgaven aan zorg en het stimuleren van de norm dat zorgen voor elkaar hoort, zouden inderdaad kunnen bijdragen aan meer inzet door mantelzorgers. Een dergelijke conclusie moet uiteraard met grote voorzichtigheid geïnterpreteerd worden. Immers, onderhavig onderzoek toont geen gevolgen van beleidswijzigingen. Het is niet uit te sluiten dat de hoogte van overheidsuitgaven aan gezondheidszorg die we op dit moment observeren in landen (en mogelijk ook de norm die in landen heerst) het gevolg zijn - en niet de oorzaak - van bepaald mantelzorggedrag. Daarnaast kan gesteld worden dat een beleidswijziging alleen het gewenste doel bereikt als deze gedragen wordt door de normatieve context (Haberkern \& Szydlik, 2010; Verbakel, 2014b).

\section{Noten}

1 Deze groep zal aangeduid worden met de term 'huisvrouw' ondanks dat 2,8\% van hen man is.

2 Deze zullen niet gerapporteerd worden in tabel 3 en 4.

3 De intraklassecorrelatie in een logistisch multiniveaumodel is te berekenen met de formule: variantie op landniveau / (variantie op landniveau $+\pi^{2} / 3$ ) (Snijders \& Bosker, 1999). Hier: 0,109/(0,109+3,29) = 0,032.

4 De intraklassecorrelatie in een lineair multiniveaumodel is te berekenen met de formule: variantie op landniveau / (variantie op landniveau + variantie op individueel niveau). Hier: 0,352 / $(0,352+1,019)=0,256$.

\section{Literatuur}

Andersen, R. \& Newman, J.F. (1973). Societal and individual determinants of medical care utilization in the United States. Health and Society, 51(1), 95-124.

Arksey, H. \& Glendinning, C. (2008). Combining work and care: Carers' decision-making in the context of competing policy pressures. Social Policy \& Administration, 42(1), 1-18.

Bengtson, V.L. \& Roberts, R.E.L. (1991). Intergenerational solidarity in aging families: An example of formal theory construction. Journal of Marriage and Family, 53(4), 856-870.

Boer, A. de, Broese van Groenou, M. \& Timmermans, J. (2009). Mantelzorg. Een overzicht van de steun van en aan mantelzorgers in 2007. Den Haag: Sociaal en Cultureel Planbureau.

Brandt, M., Haberkern, K. \& Szydlik, M. (2009). Intergenerational help and care in Europe. European Sociological Review, 25(5), 585-601.

Broese van Groenou, M. (2012). Informele zorg 3.0: Schuivende panelen en een krakend fundament. Inaugurele rede (28 juni 2012). Amsterdam: Vrije Universiteit.

Colombo, F., Llena-Nozal, A., Mercier, J. \& Tjadens, F. (2011). Help wanted? Providing and paying for long-term care. OECD Health Policy Studies, OECD Publishing.

Dautzenberg, M.G.H., Diederiks, J.P.M., Philipsen, H., Stevens, F.C.J., Tan, F.E.S. \& Vernooij-Dassen, M.J.F.J. (2000). The competing demands of paid work and parent care: 
Middle-aged daughters providing assistance to elderly parents. Research on Aging, 22(2), 165-187.

Dykstra, P.A. \& Putten, A. van (2010). Mantelzorgende mannen: een kwestie van moeten, kunnen of willen. Tijdschrift voor Sociale Geneeskunde, 88(6), 320-328.

Dykstra, P.A., Broek, T. van den, Muresan, C., Haragus, M., Haragus, P.-T., AbramowskaKmon, A. \& Kotowska, I.E. (2014). State-of-the-art report: Intergenerational linkages in families. (Preprints, FamiliesAndSocieties Working Paper Series, no 2103(1)). www. familiesandsocieties.eu/wp-content/uploads/14/12/WP01DykstraEtal2013.pdf: FP-7 funded project 'Changing families and sustainable societies: Policy contexts and diversity over the life course and across generations'. Deliverable 7.1.

Greenhaus, J.H. \& Beutell, N.J. (1985). Sources of conflict between work and family roles. The Academy of Management Review, 10(1), 76-88.

Haberkern, K. \& Szydlik, M. (2010). State care provision, societal opinion and children's care of older parents in 11 European countries. Ageing and Society, 30(2), 299-323.

Josten, E. \& De Boer, A. (2015). Concurrentie tussen mantelzorg en betaald werk. Den Haag: Sociaal en Cultureel Planbureau.

Kalmijn, M. \& Saraceno, C. (2008). A comparative perspective on intergenerational support. European Societies, 10(3), 479-508.

Klerk, M. de, Boer, A. de, Kooiker, S., Plaisier, I. \& Schyns, P. (2014). Hulp geboden. Een verkenning van de mogelijkheden en grenzen van (meer) informele hulp. Den Haag: Sociaal en Cultureel Planbureau.

Lee, Y. \& Tang, F. (2013). More caregiving, less working: Caregiving roles and gender. Journal of Applied Gerontology, 2013, advance access.

Lowenstein, A., Katz, R. \& Gur-Yaish, N. (2008). Cross-national variations in elder care: Antecedents and outcomes. In: E. Szinovacz \& A. Davey (Eds.) Caregiving contexts: Cultural, familial, and societal implications. New York: Springer Publishing Company.

Oorschot, W. van \& Arts, W. (2005). The social capital of European welfare states: The crowding out hypothesis revisited. Journal of European Social Policy, 15(1), 5-26.

Putten, A.E. van, Vlasblom, J.D., Dykstra, P.A. \& Schippers, J.J. (2010). The absence of conflict between paid-work hours and the provision of instrumental support to elderly parents among middle-aged women and men. Ageing and Society, 30(6), 923-948.

Reher, D.S. (1998). Family ties in Western Europe: Persistent contrasts. Population and Development Review, 24(2), 203-234.

Rossi, A.S. \& Rossi, P.H. (1990). Of human bonding: Parent-child relations across the life course. New York: Aldine de Gruyter.

Silverstein, M., Parrott, T.M. \& Bengtson, V.L. (1995). Factors that predispose middle-aged sons and daughters to provide social support to older parents. Journal of marriage and Family, 57(2), 465-475.

Silverstein, M., Conroy, S. \& Gans, D. (2008). Commitment to caring: Filial responsibility and the allocation of support by adult children to older mothers. In: E. Szinovacz \& A. Davey (Eds.) Caregiving contexts: Cultural, familial, and societal implications. New York: Springer Publishing Company.

Snijders, T.A.B. \& Bosker, R.J. (1999). Multilevel analysis. An Introduction To Basic And Advanced Multilevel Modeling. London: Sage.

TK (2012/13). Beleidsbrief 'Versterken, verlichten en verbinden'. Brief van de staatsecretaris van Volksgezondheid, Welzijn en Sport. Tweede Kamer, vergaderjaar 2012/13, 30 169/30 597, nr. 28.

Verbakel, E. (2014a). Informal caregiving and well-being in Europe: What can ease the negative consequences for caregivers? Journal of European Social Policy, 24(5), 424-441. 
Verbakel, E. (2014b). Toenemende publieke steun voor meer eigen verantwoordelijkheid in de zorg? Bestuurswetenschappen, 68(3), 5-23.

Verbeek-Oudijk, D., Woittiez, I., Eggink, E. \& Putman, L. (2014). Who cares in Europe? A comparison of long-term care for the over-50s in sixteen European countries. The Hague: The Netherlands Institute for Social Research.

Yates, M.E., Tennstedt, S. \& Chang, B.-H. (1999). Contributors to and mediators of psychological well-being for informal caregivers. Journal of Gerontology: Psychological Sciences, $54 B(1), 12-22$. 